\title{
СТРОЕНИЕ И БИОСТРАТИГРАФИЧЕСКАЯ ХАРАКТЕРИСТИКА ПРЖИДОЛЬСКОГО ОТДЕЛА СИЛУРА НА ГОРНОМ АЛТАЕ
}

Сенников Н. В., Новожилова Н. В., Обут О. Т., Хабибулина Р. А.

\begin{abstract}
Аннотация
Приведены новые сведения по лито- и биостратиграфии верхнего силура Горного Алтая. В осадочных образованиях этого стратиграфического интервала в Алтайском регионе установлена последовательность таксономически представительных комплексов конодонтов - средневерхнелудфордский, нижнепржидольский и нижнедевонский (лохковский-?пражский). На основе этих данных составлена новая схема сопоставления границ местных и региональных стратонов пограничных силурийско-девонских отложений Горного Алтая с ярусными границами Международной стратиграфической шкалы. Определено, что границы местных стратонов и границы базирующихся на них региональных стратиграфических подразделений силура Алтая не совпадают с границами отделов и ярусов Международной стратиграфической шкалы.
\end{abstract}

\section{Ключевые слова:}

Ключевые слова: лито-, биостратиграфия, конодонты, лудфорд, пржидол, силур, девон, черноануйская свита, Горный Алтай. 


\title{
СТРОЕНИЕ И БИОСТРАТИГРАФИЧЕСКАЯ ХАРАКТЕРИСТИКА ПРЖИДОЛЬСКОГО ОТДЕЛА СИЛУРА НА ГОРНОМ АЛТАЕ
}

\author{
${ }^{1,2}$ Сенников Н.В., ${ }^{1,2}$ Новожилова Н.В., ${ }^{1,2}$ Обут О Т., ${ }^{1}$ Хабибулина Р.А. \\ ${ }^{1}$ Институт нефтегазовой геологии и геофизики им. А.А. Трофимука СО РАН, г. \\ Новосибирск \\ ${ }^{2}$ Новосибирский государственный университет, г. Новосибирск
}

\begin{abstract}
Аннотация
Приведены новые сведения по лито- и биостратиграфии верхнего силура Горного Алтая. В осадочных образованиях этого стратиграфического интервала в Алтайском регионе установлена последовательность таксономически представительных комплексов конодонтов - средне-верхнелудфордский, нижнепржидольский и нижнедевонский (лохковско-пражский интервал). На основе этих данных составлена новая схема сопоставления границ местных и региональных стратонов пограничных силурийскодевонских отложений Горного Алтая с ярусными границами Международной стратиграфической шкалы. Определено, что границы местных стратонов и границы базирующихся на них региональных стратиграфических подразделений силура Алтая не совпадают с границами отделов и ярусов Международной стратиграфической шкалы.
\end{abstract}

Ключевые слова: лито-, биостратиграфия, конодонты, пржидол, силур, девон, черноануйская свита, Горный Алтай.

\section{Введение}

Палеонтологически охарактеризованные пржидольские отложения на территории России распространены в ограниченном числе регионов: Балтийская синеклиза, Кавказ, Урал, Новая Земля, Таймыр, Северная Земля, Горный Алтай, Тува, Северо-Восток страны. На Кавказе, в Туве, на Полярном и Южном Урале их возраст и положение границ местных подразделений относительно границ пржидола обоснованы комплексами конодонтов и граптолитов (Обут и др., 1988; Соколова, 2005; Зональная..., 2006; Краснов, Кульков, 2009; Сенников и др., 2010; Сенников, Суяркова, 2015), а в остальных регионах - только ассоциациями бентосных групп фауны, имеющих определенные ограничения при сопоставлениях с границами отделов и ярусов Международной стратиграфической шкалы силура. Во второй группе российских регионов далеко неоднозначно интерпретируется положение границ местных и региональных стратонов относительно верхней и нижней границ пржидольского отдела силура. Также по разным группам бентосной фауны не согласовано отнесение отдельных частей местных стратонов только исключительно к пржидолу или к пржидолу вместе с подстилающими его верхними частями лудловского отдела (или к пржидолу вместе с перекрывающими его нижними частями лохковского отдела). При таком положении с ограниченным объёмом сведений по определению возраста местных стратонов по ортостратиграфическим пелагическим группам фауны, крайне важны любые новые находки, особенно в их региональной последовательности от верхов лудфордского яруса силура до низов нижнего девона. Также полезно, для независимого контроля биостратиграфических выводов, использование современных данных по трансгрессивно-регрессивным трендам седиментации конца силура - начала девона (Lehnert et al., 2007a, b, 2010; Calner, 2008; Munnecke et al., 2010; Cramer et al., 2011; Антошкина и др., 2012; Антошкина, 2018).

\section{Стратиграфические данные}

Силурийские отложения на территории Горного Алтая пользуются достаточно широким распространением (см. рис. 1). Следует отметить, что осадочные образования 
силура, относимые к пржидолу, до настоящего времени известны только в четырёх структурно-фациальных зонах (СФЗ) алтайского палеобассейна: в Ануйско-Чуйской, Выдрихинской, Талицкой и Тархатинской (Сенников и др., 2019а). В последних двух СФЗ осадочные образования отнесены к пржидолу условно, по положению в разрезе, так как они пока палеонтологически не охарактеризованы. В Выдрихинской СФЗ по положению в разрезе с большей частью силура сопоставлена нижняя и средняя части антоньевской песчано-алевритовой толщи, с прослоями известняков, содержащих криноидеи. Исключительно в Ануйско-Чуйской СФЗ пржидольские образования охарактеризованы таксономически разнообразными комплексами многих групп фауны. Они известны в этой СФЗ в средней части её территории (рис. 1, В), в районе сел Черный Ануй и Турата и на севере - в районе пос. Камышенка.

В районе с. Черный Ануй выделяется черноануйская свита (Кульков, 1967), относимая по брахиоподам, остракодам и трилобитам к пржидольскому отделу силура (Кульков, 1970; Поленова, 1970; Елкин и др., 1974; Ивановский, Кульков, 1974). Черноануйская свита сложена пестроцветными песчаниками, алевролитами, с невыдержанными по простиранию прослоями серых известняков. Черноануйская свита в своем стратотипе у одноимённого села залегает на осадочных образованиях, относимых к куимовской свите. Последняя представлена там серыми глинистыми известняками, аргиллитами и алевролитами (Кульков, 1967; Елкин и др., 1974; Ивановский, Кульков, 1974). Стратотип куимовской свиты находится в Чарышско-Инской СФЗ Горного Алтая у с. Тигирек (Кульков, 1966, 1967; Елкин и др., 1974; Ивановский, Кульков, 1974; Сенников и др., 2019б). Куимовская свита коррелировалась с лудловским отделом силура (горстийский и лудфордский ярусы) (Кульков, 1966, 1967; Елкин и др., 1974; Ивановский, Кульков, 1974; Стратиграфический..., 1975; Решения..., 1983; Sennikov et al, 2008) (рис. 2). В последние годы - с гомерским ярусом венлока и лудловским отделом силура (Сенников и др., 2019б).

Некоторые исследователи предлагали в разрезах в районе с. Черный Ануй в Ануйско-Чуйской СФЗ между куимовской и черноануйской свитами выделять новую (не известную в Чарышско-Инской СФЗ Алтая, где находится стратотип куимовской свиты) марагдинскую свиту, сложенную чередованием глинистых известняков, аргиллитов, алевролитов (Миронова, 1978; Краснов и др., 1980; Стратиграфический..., 1991) (см. рис. 2). Эти авторы относили марагдинский стратон к низам пржидола. Марагдинская свита была включена в Региональную схему силура западной части Алтае-Саянской складчатой области (Решения..., 1983) и помещена на уровень нижней трети пржидола (см. рис. 2). Среднюю - наибольшую часть стратиграфического объёма пржидола занимала черноануйская свита (Решения..., 1983) (см. рис. 2). Венчала силур, при такой трактовке расчленения силурийского разреза района с. Черный Ануй, сибиркинская свита, сложенная конгломератами, гравелитами, песчаниками, с ?линзами песчанистых известняков (Решения..., 1983). Грубообломочная толща, отнесённая в районе Черного Ануя к сибиркинской свите, при первом её изучении включалась в состав черноануйской свиты (Кульков, 1967; Ивановский, Кульков, 1974), а затем была отделена от неё и отнесена к девону (Асташкина, 1974). Позднее (Краснов и др., 1980; Решения..., 1983) грубообломочную последовательность сибиркинской свиты района с. Черный Ануй стали относить к верхней трети пржидола (см. рис. 2). При этом, те же специалисты (Краснов и др., 1980) на базе упомянутых свит предложили выделять и горизонты, соответственно, марагдинский, черноануйский и сибиркинский, уменьшив более чем на треть объем черноануйского горизонта (Ивановский, Кульков, 1974).

Региональных стратонов (горизонтов) в Стратиграфической схеме силура западной части Алтае-Саянской складчатой области 1979 г. (Решения..., 1983) в пржидоле официально принято не было (см. рис. 2).

Авторами черноануйского горизонта являются А.Б. Ивановский и Н.П. Кульков (1974). Его выделение основывалось на данных по черноануйской свите окрестностей с. Черный Ануй в Ануйской-Чуйской СФЗ Алтая и на сведениях по боровушкинскому 
известняку и отложениям у с. Камышенка в северной части Алтая. Черноануйский горизонт (и его «типовая» черноануйская свита) был сопоставлен со всем объемом пржидола Общей стратиграфической шкалы силура (Ивановский, Кульков, 1974; Стратиграфический..., 1991; Sennikov et al., 2008) (см. рис. 2).

Для силурийских отложений Горного Алтая уже многие годы предметом дискуссии является хроностратиграфическое положение черноануйского и подстилающего его куимовского горизонтов, что в определённой мере связано со спорностью строения их типовых одноименных свит - выделять или не выделять марагдинскую и сибиркинскую свиты. Черноануйский горизонт соотносят с пржидолом или с началом девона ? (с лохковом), а подстилающий его куимовский горизонт - с лудловом (с горстийским и лудфордским ярусами). В других случаях рассматриваемый горизонт сопоставляется с лудловом и пржидолом (Кульков, 1967, 1970; Поленова, 1970; Елкин и др., 1974; Ивановский, Кульков, 1974; Миронова, 1978; Краснов и др., 1980; Елкин, 1983; Стратиграфический..., 1991; Гутак и др., 2000; Sennikov et al., 2008; Краснов, Кульков, 2009; Сенников и др., 2010; Сенников и др., 2014, 2018, 2019а, б; Абушик, Савина, 2018) (см. рис. 2).

Геолого-съемочные работы в районе с. Чёрный Ануй (Государственная ..., 2001а, б) (см. рис. 2) показали, что (марагдинскую) часть разреза по сходству литологии следует рассматривать как верхнюю часть куимовской свиты, в связи с чем она стала именоваться марагдинской пачкой (или подсвитой) куимовской свиты (Сенников и др., 2014, 2019а. б). При выделении марагдинского стратона (Миронова, 1978) (см. рис. 2) было зафиксировано, что в нем присутствуют комплексы табулят, отличающиеся от комплексов табулят черноануйской свиты, но оба эти коралловые комплексы следует считать пржидольскими. При этом другие бентосные группы (ругозы, брахиоподы, трилобиты, остракоды и др.) марагдинской части разреза куимовской свиты указывали на лудловский уровень вмещающих их отложений (Кульков, 1967; Поленова, 1970; Краснов и др., 1980; Гутак и др., 2000; Краснов, Кульков, 2009). Предполагалась необходимость специального изучения возраста марагдинской части разреза (Стратиграфический.., 1991). В одной из последних работ по анализу состава комплекса остракод из известняков стратотипа черноануйской свиты сделан вывод о том, что «...черноануйский комплекс остракод больше тяготеет к девонскому возрасту» (Абушик, Савина, 2018, с. 46).

Первые находки конодонтов в марагдинской пачке верхов куимовской свиты Acodina cf. curvata Stauffer, Belodella resima (Philip), Panderodus sp., Hindeodella sp., Ozarkodina sp., Trichnodella sp., а в черноануйской свите - Plectospathodus sp. (Гутак и др., 2000) не дали однозначного ответа о возрасте отложений. Эти таксоны позволяли предполагать широкий стратиграфический интервал - от лудлова до лохкова. В то же время, в связи с этой информацией по стратиграфическому распространению найденных таксонов конодонтов был сделан вывод (Гутак и др., 2000) о вероятном положении границы силура и девона в верхах марагдинской пачки и, таким образом, вся вышележащая черноануйская свита была отнесена к низам девона.

В последние годы по материалам изучения конодонтов и граптолитов были получены биостратиграфические данные о поздневенлокском (гомерском) возрасте нижней части куимовской свиты (Сенников и др., 2001; Sennikov et al., 2008; Обут и др., 2013; Сенников и др., 2019б). В связи с этим, нижняя граница куимовской свиты (и куимовского горизонта) в Региональной стратиграфической схеме силура западной части АлтаеСаянской складчатой области (Сенников и др., 2019а) была сопоставлена с нижней границей гомерского яруса Общей (Международной) стратиграфической шкалы (см. рис. 2).

В литературе имеется несоответствие, выражающееся в том, что черноануйский горизонт отвечает всему объёму пржидола, а его одноимённая типовая свита - только средней части пржидола (Ивановский, Кульков, 1974; Краснов, Кульков, 2009). Авторы настоящей статьи (Sennikov et al., 2008; Сенников и др., 2019а, б) на основе синтеза 
биостратиграфической информации черноануйскую свиту (и, соответственно черноануйский горизонт) до последнего времени соотносили со всем стратиграфическим объёмом пржидола, а подстилающую её куимовскую свиту (и, соответственно, одноименный горизонт) относили к лудловскому отделу, как это было зафиксировано в Стратиграфическом словаре (1991). Граница между лудловским и пржидольским отделами силура на Горном Алтае, с определённой долей условности, сопоставлялась с границей между куимовским и черноануйским горизонтами (Сенников и др., 2010, 2014; Сенников и др., 2019б). Такой вариант полного объёма пржидольского возрастного интервала, занимаемого черноануйским горизонтом, был подтверждён в последней официальной Региональной стратиграфической схеме силура западной части Алтае-Саянской складчатой области, принятой в 2012 г. и утверждённой Межведомственным стратиграфическим комитетом России в 2014 г. (Сенников и др., 2019а).

Следует особо отметить, что в стратотипе черноануйской свиты её взаимоотношения с подстилающей куимовской свитой носят тектонический характер (см. рис. 1, С, разрез Черный Ануй-2).

\section{Седиментологические данные по верхней части силура Горного Алтая}

На Горном Алтае в силурийских разрезах лландоверийского, венлокского и нижней части лудловского (горстийский ярус) отделов силура достаточно однозначно с применением зонального биостратиграфического метода (граптолиты и конодонты) фиксируются следы глобальных седиментационных событий Иревикен (Ireviken), Мульде (Mulde), Линде (Linde) (Sennikov et al., 2008; Сенников и др., 2019б). Следы трансгрессивного седиментационного среднелудфордского события Лау (Lau) высокого стояния уровня моря и регрессивного седиментационного пржидольского события Клев (Klev) низкого стояния уровня моря (Lehnert et al., 2007a, 2010; Calner, 2008; Munnecke et al., 2010; Cramer et al., 2011) на алтайских материалах пока подробно не рассматривались. А по данным (Calner, 2008) при этих двух отмеченных глобальных событиях происходило резкое изменение уровня моря на 30 метров, что могло и должно было отразиться на седиментационном процессе в алтайском силурийском бассейне.

Выделение в нижнепалеозойских стратифицированных образованиях Горного Алтая местных подразделений (свит), как картируемых геологических тел, обычно основывалось на резкой смене карбонатного типа седиментации на терригенный тип или терригенного на карбонатный. Зафиксированное в силурийских разрезах Алтая появление и последующее доминирование терригенной седиментации, произошедшее после устойчивого карбонатного и терригенно-карбонатного осадконакопления, характерного для куимовской свиты, дополненное информацией о появлении новых фаунистических ассоциаций, привели к выделению черноануйской свиты (Кульков, 1967). Таким образом, уже при выделении черноануйского местного стратона его нижняя граница косвенно отождествлялась с масштабной регрессией. Гравелиты и песчаники с плавающей галькой в базальных пачках стратотипа черноануйской свиты (разрез Черный Ануй-2 - см рис. 3) указывают на максимальное проявление такой регрессии у основания этой свиты. В настоящее время литологические следы такого резкого появления обмеления силурийского алтайского бассейна можно связать с влиянием глобального регрессивного седиментационного события Клев (Klev), сопровождавшимся падением уровня мирового океана не менее чем на 30 м. В районе с. Черный Ануй в залегающих стратиграфически ниже черноануйской свиты разрезах куимовской свиты, в верхней их части, среди глинистых известняков появляются обособленные прослои известковистых алевролитов (разрез Марада-5, см. рис. 1, С). Такие терригенные прослои могут свидетельствовать о начале регрессии, связанной с глобальным регрессивным событием Клев (Klev).

Изучение стратотипа черноануйской свиты (Разрез Черный Ануй-2) у одноименного села позволило составить его детальный составной разрез (см рис. 2). В разрезе четко обособились три части: а) терригенная - песчаники, редко гравелиты и 
алевролиты (пачки с первой по 7-ую включительно); б) терригенно-карбонатная известковистые алевролиты и не выдержанные по простиранию слои и линзы известняков (пачки с 8-ую по 24-ую включительно); в) терригенная - песчаники, в верхах с плавающими гальками (пачки с 25-ой по 29-ую включительно). Следует отметить, такое наблюдаемое трёхчленное строение черноануйского местного стратона позволило ранее (Ёлкин и др., 1974) высказать предложение рассматривать черноануйский стратон в ранге серии, состоящей из нескольких толщ. Данные авторов настоящей статьи (Sennikov et al., 2008), подкреплённые материалами геологического картирования (Государственная..., 2001a, б) указывают на необходимость эти три части черноануйской свиты рассматривать в стратотипе свиты (разрез Черный Ануй-2) в виде обособленных, резко отличающихся друг от друга нижней, средней и верхней подсвит. Следует обратить внимание, что по материалам разрезов Бурта-3 и Марагда-5, представленные в них низы черноануйской свиты сложены аргиллитами с редкими стяжениями («желваками») и маломощными слоями известняков. То есть, деления на подсвиты черноануйской свиты в разрезах Бурта3 и Марагда-5 не представляется возможным. Согласно примечания к статье V.10 Стратиграфического кодекса (2019), свита подразделённая на подсвиты в одном районе, может быть не расчленяющейся на подсвиты в другом.

\section{Новая биостратиграфическая информация по верхней части силура Горного Алтая}

Авторы настоящей статьи за последние 10 лет изучили и составили серию детальных разрезов куимовской и черноануйской свит в верхнем течении р. Ануй, в районе сёл Черный Ануй и Турата. В каждом из изучаемых разрезов многократно, в течении нескольких полевых сезонов, целенаправленно, послойно отбирались крупные (от 1-3 до 5-10 кг) пробы известняков для микропалеонтологического изучения.

Рассмотрим наиболее представительные из этих разрезов, в образцах известняков из которых при лабораторных исследованиях удалось получить последовательно сменяющие друг друга, таксономически разнообразные комплексы конодонтов. Коллекция изученных конодонтов хранится в ЦКП "Геохрон" при Институте нефтегазовой геологии и геофизики СО РАН в г. Новосибирске под № 2100. Сохранность найденных платформенных и конических конодонтовых элементов удовлетворительная, реже хорошая. Для силурийской части изученных разрезов доминируют представители родов Ozarkodina Branson et Mehl и Zieglerodina Murphy et al., для девона же представители этих родов крайне редки, появляются единичные платформенные и многочисленные конические элементы Icriodus Branson et Mehl.

В разрезе Бурта-3 у с. Турата в верхней подсвите куимовской свиты (отметим, что там марагдинская подсвита не выделяется) найдено несколько стратиграфических уровней с конодонтами (рис. 4, 5) - в первой и в 8-ой пачках разреза, из глинистых известняков определены единичные Panderodus sp., с широким стратиграфическим интервалом их возможного стратиграфического распространения. В 9-ой пачке разреза Бурта-3, в органогенных известняках установлены многочисленные Zieglerodina remscheidensis (Ziegler), Zieglerodina cf. remscheidensis (Ziegler), Ozarkodina cf. confluens (Branson et Mehl), Ozarkodina sp. Этот комплекс позволяет отнести вмещающие породы к низам пржидола. Следует отметить, что отдельные элементы этого комплекса могут появляться в самых верхах лудфорда (Kaljo et al., 2014), что свидетельствует о некоторой условности проведения нижней границы пржидола в разрезе Бурта-3. В верхах куимовской свиты в разрезе Бурта-3, в известняках 20-той пачки найдены обломки конодонтов Ozarkodina sp.

Как уже отмечалось выше, нижняя часть черноануйской свиты в разрезе Бурта-3, в отличие от стратотипического разреза этой свиты в разрезе Черный Ануй-2 представлена не псаммитовыми пачками, а пеллитовыми. Однако, в работе (Ивановский, Кульков. 1974) отмечается, что в основании черноануйского горизонта в стратотипической местности одноименной свиты могут залегать зеленые и бордовые алевролиты. 
В разрезе Марагда-5 (рис. 2, С; рис. 6, 7) у с. Черный Ануй в низах верхней части марагдинской подсвиты куимовской свиты при растворении глинистых известняков первой и 4-ой пачек разреза установлены конодонты Ozarkodina sp., а в 6-ой пачке разреза найдены Ozarkodina sp., Panderodus sp. B известняках 7-ой пачки были получены конодонты Wurmiella excavata (Branson et Mehl), Ozarkodina sp., Panderodus sp., Oulodus ? sp., которые не противоречат отнесению этой части рассматриваемого разреза к лудфордскому ярусу лудловского отдела силура. Кроме того, следует добавить, что на уровне нижней части разреза Марагда-5 в соседнем, расположенном 100-150 м южнее логу, расположен разрез Марагда-4 со сходным комплексом конодонтов (см. ниже).

Стратиграфически выше в разрезе Марагда-5, в 9-ой его пачке (см рис. 6, 7), в терминальной части марагдинской подсвиты куимовской свиты в массивных известняках найден таксономически другой комплекс конодонтов - Ozarkodina eosteinhornensis (Walliser), Ozarkodina cf. remscheidensis (Ziegler), Ozarkodina cf. multistriola Mathieson et al., Ozarkodina sp. В составе этого комплекса преобладают виды рода Ozarkodina Branson et Mehl, характерные для нижнего пржидола, Таксоны Oz. eosteinhornensis (Walliser) и Oz. remscheidensis (Ziegler) являются видами-индексами зональных подразделений, установленных для пржидола (Corradini, 2007; Corriga et al., 2009; Gradstein et al., 2012; Spiridonov et al, 2020 и др.). Видовой таксон Oz. multistriola Mathieson et al. ранее был известен только из девона Австралии (Mathieson et al., 2016). В то же время, следует отметить, что публикации последних лет показывают, что в комплексах конодонтов переходных слоев между лудфордом и пржидолом, некоторые таксоны, например, установленный на Алтае вид Ozarkodina eosteinhornensis (Walliser), могут появляться в разрезах, относимых к самым верхам верхнелудфордскому подъяруса, то есть, стратиграфически несколько ниже нижней границы пржидольского отдела силура (Corriga et al., 2009; Corradini, Corriga, 2010; Slavik, Carls, 2012; Kaljo et a., 2014; Slavik et al., 2014; Huskova, Slavik, 2019).

Анализ опубликованных данных по стратиграфическому распространению конодонтовых таксонов в интервале лудфорда и пржидола (Murphy et al., 2004; Boncheva et al., 2007; Corriga, Corradini, 2009; Corriga et al., 2009; Corradini, Corriga, 2010; Slavik et al., 2010, 2014; Slavik, Carls, 2012; Spiridonov, Brazauskas, 2014; Mathieson et al., 2016; Spiridonov et al., 2018, 2020) на современном этапе изучения позволяют отдать предпочтение интерпретации возраста верхней части разреза куимовской свиты в разрезе Марагда-5 началом пржидольского века.

Отметим, что в разрезе Марагда-5 базальная пачка черноануйской свиты, сложенная аргиллитами, сходна с низами этой свиты в разрезе Бурта-3, при этом резко отличается от песчаного базального горизонта черноануйской свиты в её стратотипическом разрезе Черный Ануй-2.

В разрезе Марагда-4 (рис. 2, С; рис. 8) конодонты встречены на двух уровнях: в верхней части 1-ой пачки обнаружены конодонты (см рис. 7) Oulodus ? sp., Wurmiella excavata (Branson et Mehl), Ozarkodina cf. snajdri (Walliser), Ozarkodina sp., а в средней части 5-ой пачки найдены Oulodus ? sp., Ozarkodina cf. snajdri (Walliser), Panderodus unicostatus Branson et Mehl. Разрез Марагда-4 по литологии может быть сопоставлен с нижней часть разреза Марагда-5 (первая, вторая и третья пачки).

В разрезе Черный Ануй-2 (см рис. 3), являющемся стратотипом одноименной свиты, конодонты найдены в нескольких пачках в его средней терригенно-карбонатной части. В 10-ой пачке разреза в темных, почти черных известняках определены конодонты Peleksygnathus sp., Ozarkodina sp., Panderodus sp. Стратиграфически выше, в 18-ой пачке, в черных и темно-серых известняках установлены конодонты (рис. 9) Zieglerodina mashkovae (Drygant), Peleksygnatus sp., Icriodus cf. angustoides Carls et Gandl, Icriodus cf. curvicauda Carl et Gandl, Icriodus sp.,?Eognathodus sp., Panderodus sp. Этот комплекс конодонтов по содержащимся в нём таксонам кардинально отличается от пржидольских комплексов конодонтов, встреченных в разрезах Бурта-3 и Марагда-5. Комплекс 
конодонтов 18-ой пачки разреза Черный Ануй-2 безусловно указывает на раннедевонский возраст вмещающих отложений. Стратиграфически выше, в 20-ой пачке найдены Peleksygnathus sp., в 22-ой пачке - Peleksygnathus sp., Panderodus sp., Ozarcodina sp., а ещё выше, в 24-ой пачке - Panderodus sp.

Вопрос находок в разрезе Черный Ануй-2, в низах его девонской части конодонтов Icriodus cf. angustoides Carls et Gandl, Icriodus cf. curvicauda Carl et Gandl, ?Eognathodus sp. требует специального дополнительного изучения, так как таксоны Ic. angustoides Carls et Gandl, Ic. curvicauda Carl et Gandl, Eognathodus sp. более характерны для ранней праги, чем для позднего лохкова.

\section{Дискуссия}

Характерные для черноануйского горизонта таксоны брахиопод, трилобитов, остракод, ругоз, строматопорат, по которым рассматриваемый горизонт сопоставлялся с пржидольским отделом силура, были собраны в нижней терригенной части разреза Черный Ануй-2 и в нижней половине его терригенно-карбонатной части - пачки с 5-ой по 16-ую (см рис. 3). Таким образом, бентосные фаунистические сообщества черноануйской свиты и, что более важно, широко известная, общепринятая палеонтологическая характеристика черноануйского горизонта, продолжают большинством специалистов соотноситься только с пржидольским отделом силура. Новая дополнительная информация по распространению пелагической группы фауны второй половины стратотипа черноануйской свиты - конодонтовый комплекс с Zieglerodina mashkovae (Drygant), Peleksygnatus sp., Icriodus cf. angustoides Carls et Gandl, Icriodus cf. curvicauda Carl et Gandl, Icriodus sp.,?Eognathodus sp., Panderodus sp. отвечает более молодому раннедевонскому стратиграфическому интервалу.

При корреляционных сопоставлениях всю черноануйскую свиту следует рассматривать как стратон пограничного силурийско-девонского возраста. Для черноануйского горизонта, стратотип которого отвечает стратотипу его типовой одноимённой свиты (разрез Черный Ануй-2), его хроностратиграфический объём увеличивается более чем на $1 / 3$, на что обращено внимание в статье XII.10 Стратиграфического кодекса России (2019). Это заставляет, для соблюдения преемственности и сохранения термина черноануйский региостратон, и выполняя требования (Стратиграфический..., 2019), перевести широко используемый ранее черноануйский горизонт, в ранг надгоризонта. Нижняя часть этого надгоризонта, соответствующая нижней терригенной части разреза Черный Ануй-2 и первой половине его терригенно-карбонатной части, должна обособиться в новый терминальный силурийский региостратон Горного Алтая, соответствующий по объёму большей части пржидольского отдела силура. Согласно (Стратиграфический..., 2019, статья IV.8б), если горизонт основывается на материалах подсвиты без собственного наименования, то для него выбирается новое название. Такой горизонт можно именовать чергинским горизонтом по наименованию реки, в левобережье которой расположен стратотип как самого горизонта, так и черноануйской свиты (см рис. 3). В современной стратиграфической терминологии название «чергинский» для палеозойских местных и региональных стратонов Горного Алтая не используется (Стратиграфический..., 1975).

Географического распространение нового чергинского горизонта пока ограничено территорией северной части Ануйско-Чуйской СФЗ Алтая. В качестве стратотипа чергинского горизонта предлагается нижняя терригенная часть и нижняя половина терригенно-карбонатной части разреза Черный Ануй-2 - пачки с 1-ой по 16-ую (см рис. 3). Нижняя граница чергинского горизонта, не вскрытая в стратотипе черноануйской свиты, может быть принята в разрезе Марагда-5, который предлагается считать лимитотипом основания чергинского горизонта (Стратиграфический..., 2019, Приложение, статья 1.3). В разрезе Марагда-5 нижняя граница чергинского горизонта проходит в основании 12-ой пачки в кровле марагдинской подсвиты куимовской свиты (см рис. 6). Новый чергинский 
горизонт в стратиграфической схеме силура западной части Алтае-Саянской складчатой области будет являться терминальным региостратоном, занимая хроностратиграфическое положение большей части пржидола (без самых низов этого яруса, относимых к верхам нижележащего куимовского горизонта).

Для верхнего горизонта черноануйского надгоризонта, отвечающего девонской его части, можно использовать формальный термин - верхний горизонт черноануйского надгоризонта или применить новый термин - елбакский, по наименованию ручья, в правобережье которого расположена г. Марагда, на одном из отрогов которой расположен разрез Черный Ануй-2 (см рис. 1, С). Стратотипом елбакского горизонта предлагается считать последовательность пачек этого разреза с 17-ой по 29-тую. К сожалению, в 17-ой пачке разреза Черный Ануй-2 пока не найдено конодонтов, что могло бы позволить уточнить положение силурийско-девонской границы. Употребление названия «верхнечерноануйский» горизонт с использованием приставки «верхне-» запрещается Приложением 3, параграфом 1.6 Стратиграфического кодекса (2019). Нельзя исключить того, что этот пионерный региональный хроностратиграфический интервал нижнего девона пока не фиксировался в других разрезах Горного Алтая. Для его аргументированного обоснования в виде самостоятельного («елбакского») горизонта Горного Алтая необходимо дополнительно к палеонтологическим пелагическим параметрам определения его нижней границы (появление раннедевонского комплекса конодонтов) выбрать, по возможности, и какие-либо изменения в комплексах бентосных группах фауны. То есть, изучить таксономический состав прежде всего брахиопод, по которым первоначально и был выделен пржидольский черноануйский горизонт, затем трилобитов, так как эта группа имеет маркёрный вид-индекс Warburgella rugulosa rugosa в глобальном лимитотипе (ГСРТ - GSSP) нижней границы девона Клонк (Klonck) в чешском Баррандиене (Gradstein et al., 2012), а также остракод, ругоз и табулят. Следует отметить, что спорадические находки этих отмеченных выше групп фауны в виде захоронений плохой сохранности уже были зафиксированы авторами настоящей статьи в разрезе Черный Ануй-2 (см рис. 3). Следует напомнить, что по современному анализу состава комплекса остракод из карбонатно-терригенной, средней части стратотипа черноануйской свиты сделан вывод о девонском возрасте вмещающих отложений (Абушик, Савина, 2018).

Для официального признания валидности нового елбакского горизонта предстоит определить его стратиграфические взаимоотношения с выделяемым на Салаире кайбальским горизонтом (сухие и томско-заводские слои нижнего девона) (Язиков, Изох, 2014). Ранее термин кайбальский региостратон применялся в ранге надгоризонта (Елкин и др., 1982; Бахарев и др., 2004; Bakharev et al., 2011). В официальной «Региональной стратиграфической схеме девонских отложений Рудного и Горного Алтая» (Решения..., 1982) базальными девонскими региостратонами являлись сухой и томь-чумышский горизонты.

Приведенные новые материалы исследований показывают, что хроностратиграфическое положение границы куимовского и черноануйского горизонтов, официально соответствующее границе куимовской и черноануйской свит, ранее (Сенников и др., 2019а, б) отождествляемое с границей лудловской и пржидольской эпох позднего силура, требует уточнения. В настоящее время основание пржидольского отдела силура по конодонтовому комплексу с Ozarkodina eosteinhornensis (Walliser), Ozarkodina cf. remscheidensis (Ziegler), Ozarkodina cf. multistriola Mathieson et al. проведено на Алтае стратиграфически ниже, в верхах куимовской свиты (основание терминальной части марагдинской подсвиты куимовской свиты) - подошва 9-ой пачки разреза Марагда-5. Таким образом, куимовский горизонт, соответствующий её типовой одноимённой свите (Стратиграфический..., 2019, статья IV.8), должен коррелироваться не только с гомерским ярусом венлока, горстийским и лудфордским ярусами лудлова (Сенников и др., 2019а), но и с низами пржидола. Возможно, куимовский горизонт следует подразделять на слои с 
географическими названиями по специфике литологии и особенностям комплексов фауны или рассматривать его в ранге надгоризонта, с делением на несколько новых горизонтов.

На таблице (рис. 2) показана существующая «мозаичная картина» ранее используемых схем расчленения верхнего силура Горного Алтая. Она отражает многовариантность корреляций разрезов как самих местных стратонов, так и базирующихся на них горизонтах. Особенно дискуссионными являются хроностратиграфические объёмы стратонов, то есть, сопоставления их границ с границами ярусных подразделений Международной стратиграфической шкалы (МСШ). Предлагаемое взаимоувязанное соотнесение положения местных стратонов и региостратонов верхней части силура северо-западной части Горного Алтая (АнуйскоЧуйская и Чарышско-Инская СФЗ) с одной стороны, и ярусных подразделений МСШ с другой, синтезирует, по возможности, все накопленные в настоящее время, не противоречащие друг другу био- и литостратиграфические данные.

\section{Заключение}

Приведенные материалы позволяют отметить следующее.

1. В палеозойской последовательности осадочных образований Горного Алтая присутствуют достаточно представительные комплексы конодонтов пограничных лудлов/пржидольского и пржидол/лохковск--пражского стратиграфических интервалов.

2. В уточнение официальной региональной стратиграфической схемы силурийских отложений западной части Алтае-Саянской складчатой области (Sennikov et al., 2008; Сенников и др., 2018, 2019а) показано, что границы местных стратонов и границы базирующихся на них региональных стратиграфических подразделений силура Алтая не совпадают с границами отделов и ярусов верхнего силура МСШ.

3. Зафиксирован дискуссионный момент о хроностратиграфическом положении границы куимовского и черноануйского региональных стратонов (горизонтов) относительно границы лудловской и пржидольской эпох силура МСШ. Верхняя граница куимовского горизонта (и соответствующая граница его типовой одноимённой свиты) находится выше нижней границы пржидольского отдела силура.

4. Черноануйскую свиту следует делить на три подсвиты - нижнюю терригенную, среднюю терригенно-карбонатную и верхнюю терригенную. Нижняя и первая половина средней подсвиты имеют пржидольский возраст, а вторая часть средней подсвиты и верхняя подсвита черноануйской свиты имеют раннедевонский возраст.

5. В районе сел Черный Ануй и Турата имеются разрезы черноануйской свиты отличающиеся по литологии от состава пород её стратотипа, что свидетельствует об её фациальной невыдержанности по латерали, связанной с различными глубинами формирования пород и удаленности от областей сноса материала.

6. Следует воздержаться от использования термина черноануйский горизонт. Для сохранения преемственности предлагается повысить ранг черноануйского региостратона и использовать его в качестве надгоризонта. Для силурийской части разреза Черный Ануй-2 (нижняя терригенная подсвита и нижняя половина средней терригенно-карбонатной подсвиты черноануйской свиты), содержащей комплексы брахиопод, трилобитов, ругоз и других бентосных групп фауны, по которым проводилась внутрирегиональная биостратиграфическая корреляции разрезов верхов силура Горного Алтая и Салаира, следует выделить региональное стратиграфическое подразделение с новым названием. Предлагается наименование - чергинский горизонт. Этот новый горизонт будет соответствовать нижнему горизонту черноануйского надгоризонта и сопоставляться с пржидольским отделом силура без самых его низов. Базальная часть пржидола соответствует терминальной части куимовского горизонта (верхушка марагдинской подсвиты куимовской свиты в разрезе Марагда-5).

Авторы отдают себе отчет дискуссионности некоторых положений статьи. Понятно, что рано считать окончательным решение проблемы определения точного 
стратиграфического положения границы силур-девон в конкретных разрезах местных и региональных стратонов в западной части Алтае-Саянской складчатой области. Представляется, что предпринятый в настоящей статье анализ этой проблемы на новом палеонтологическом материале, с использованием ортостратиграфической группы конодонтов и современных лито- и биостратиграфических данных, позволит в дальнейшем существенно повысить точность региональных стратиграфических корреляций, геологических обобщений и палеогеографических реконструкций.

Авторы статьи координируют свои исследования с Международным проектом IGCP (МПГК) № 652.

\section{Литература}

Абушик А.Ф., Савина Н.И. Остракоды черноануйской свиты Горного Алтая // Региональная геология и металлогения. 2018. № 73. С. 45-49.

Антошкина А. И. Проявление лудфордского события Лау (верхний силур) на северо-востоке Европейской части России // Стратиграфия. Геологическая корреляция. 2018. Том. 26, № 6. С. 15-40.

Антошкина А.И., Валяева О В., Исаенко С.И., Процько О.С. Черные аргиллиты верхнего лудфордия как свидетельство эвксинных условий, Полярный Урал // Геохимия. 2012. № 12. С. 1154-1160.

Асташкина В.Ф. Стратотипический разрез черноануйской свиты пржидолия в Горном Алтае. Материалы по стратиграфии и палеонтологии Сибири. Тр. СНИИГГиМС, вып. 192. Новосибирск. Изд-во СНИИГГиМС. 1974. С. 58-62.

Бахарев Н.К., Сенников Н.В., Елкин Е.А., Изох Н.Г., Алексеенко А.А., Обут О.Т., Родина О.А., Сараев С.В., Батурина Т.П., Киприянова Т.П., Тимохина И.Г., Язиков А.Ю. Ключевые разрезы девона Рудного Алтая, Салаира и Кузбасса. Новосибирск. Изд-во СО PAH. 2004. 103 с.

Государственная геологическая карта Российской Федерации масштаба 1:200.000. Серия Алтайская. Лист M-45-I (Солонешное). Санкт-Петербург: Изд-во СанктПетербургской картографической фабрики ВСЕГЕИ. 2001а. Объяснительная записка. 183 с.

Государственная геологическая карта Российской Федерации масштаба 1:200 000. Издание второе. Серия Алтайская. M-45-VII (Усть-Кан). Санкт-Петербург. Из-во СанктПетербургская картографическая фабрика ВСЕГЕИ. 2001б. Объяснительная записка. - 171 c.

Гутак Я.М., Абушик А.Ф., Савина Н.И., Родыгин С.А. Черноануйская свита и проблема пржидольского яруса верхнего силура в Горном Алтае // Материалы региональной конференции геологов Сибири, Дальнего Востока и Северо-Востока России. T. II. Глава III. Палеонтология и стратиграфия. - Томск: ОГУП «Асиновская типография», 2000. - С. 290-294.

Елкин Е.А. Закономерности эволюции дехенеллид и биохронология силура и девона. - М.: Наука - 1983. - 116 с.

Елкин, Е.А. Грацианова Р.Т., Желтоногова В.А., Ким А.И. Основные биостратиграфические рубежи и подразделения нижнего и среднего девона на западе Алтае-Саянской области и их корреляция // Биостратиграфия пограничных отложений нижнего и среднего девона. - Л.: Наука, 1982. - С. 65-80.

Елкин Е.А., Желтоногова В.А., Сенников Н.В., Базарова Л.С. Древнейшие дехенеллиды (трилобиты) и стратиграфия силура Горного Алтая. - Новосибирск: Наука, 1974. - 90 с.

Зональная стратиграфия фанерозоя России. Санкт-Петербург: ВСЕГЕИ, 2006. 255 с.

Ивановский А.Б., Кульков Н.П. Ругозы, брахиоподы и стратиграфия силура АлтаеСаянской горной области. - М.: Наука, 1974. - 96 с. 
Краснов В.И., Асташкина В.Ф., Миронова Н.В., Ратанов Л.С., Степанов С.А., Черепнина С.К., Ярошинская А.М. Пограничные отложения силура и девона в АлтаеСаянской области. Девон и карбон Азиатской части СССР. - Новосибирск: Наука, 1980. C. 63-81.

Краснов В.И., Кульков Н.П. Пржидольский ярус и силурийско-девонская граница в Сибири // Региональная геология, стратиграфия и палеонтология фанерозоя Сибири. Новосибирск: СНИИГГиМС, 2009. - С. 39-51.

Кульков Н.П. К стратиграфии силурийских отложений Горного Алтая // Бюлл. Моск. об-ва испыт. природы, отд. геологии. 1966, том 41, вып. 1. - С. 77-82.

Кульков Н.П. Брахиоподы и стратиграфия силура Горного Алтая. - М.: Наука, 1967. -151 c.

Кульков Н.П. Биостратиграфическое сопоставление силурийских отложений Горного Алтая и Салаира // Геология и геофизика. 1970, № 6. С. 72-79.

Миронова Н.В. Некоторые пржидольские табуляты Центрального Алтая // Фауна и биостратиграфия верхнего одовика и силура Алтае-Саянской складчатой области. - М.: Наука, 1978. - С. 104-117.

Обут А.М., Морозова Ф.И., Москаленко Т.А., Чегодаев Л.Д. Граптолиты, конодонты и стратиграфия силура, нижнего девона Северного Кавказа. - Новосибирск: Наука, 1988. 221 c.

Обут О.Т., Изох Н.Г., Сенников Н.В. Новые находки силурийских конодонтов в куимовской свите западной части Горного Алтая // Интерэкспо ГЕО-Сибирь-2013. IX Междунар. науч. конгр., 15-26 апреля 2013 г., Новосибирск: Междунар. науч. конф. «Недропользование. Горное дело. Новые направления и технологии поиска, разведки и разработки месторождений полезных ископаемых. Геоэкология»: сб. материалов в 3 т. Т. 1. - Новосибирск: СГГА, 2013. - С. 69-72.

Поленова Е.Н. Остракоды позднего силура и раннего девона Алтае-Саянской области. - М.: Наука, 1970. - 104 с.

Решения Всесоюзного стратиграфического совещания по докембрию, палеозою и четвертичной системе Средней Сибири, Новосибирск, 1979. Часть I. Верхний протерозой и нижний палеозой. - Новосибирск, 1983. - 215 с.

Решения Всесоюзного стратиграфического совещания по докембрию, палеозою и четвертичной системе Средней Сибири, Новосибирск, 1979. Часть II. Средний и верхний палеозой. - Новосибирск. - 1982. - 128 с.

Сенников Н.В., Изох Н.Г., Алексеенко А.А., Бахарев Н.К., Елкин Е.А., Клец А.Г., Обут О.T., Родина О.А. Новые палеонтолого-стратиграфические данные по «пограничным» силурийско-девонским разрезам Тувы. - Новосибирск: СНИИГГиМС, 2010. - С. 129-146.

Сенников Н.В., Изох Н.Г., Елкин Е.А., Петрунина 3.Е. Первые сведения о лудловских конодонтах Горного Алтая. Эволюция жизни на Земле. Томск. Изд-во научнотехнической литературы. 2001. С. 223-225.

Сенников Н.В., Новожилова Н.В., Обут О.Т., Хабибулина Р.А. О хроностратиграфическом положении границы куимовского и черноануйского горизонтов силура на Горном Алтае. // Интерэкспо ГЕО-Сибирь-2018. XIV Междунар. науч. конгр. и выставка, 23-27 апреля 2018 г., Новосибирск: Междунар. науч. конф. «Недропользование. Горное дело. Направления и технологии поиска, разведки и разработки месторождений полезных ископаемых. Экономика. Геоэкология»: сб. материалов в 6 т. Т 1. - Новосибирск: СГУГиТ, 2018. С. 121-127.

Сенников Н.В., Обут О.Т., Изох Н.Г., Родина О.А., Хабибулина Р.А. Новые данные и проблемные вопросы стратиграфии силура западной части Алтае-Саянской складчатой области // Интерэкспо ГЕО-Сибирь-2014. Х Междунар. науч. конгр., 8-18 апреля 2014 г., Новосибирск: Междунар. науч. конф. «Недропользование. Горное дело. Направления и 
технологии поиска, разведки и разработки месторождений полезных ископаемых. Геоэкология»: сб. материалов в 4 т.- Новосибирск: СГГА, 2014. - Т. 1. - С. 130-136.

Сенников Н.В., Обут О.Т., Изох Н.Г., Хабибулина Р.А., Родина О.А., Лыкова Е.В. Киприянова Т.П. Региональная стратиграфическая схема силурийских отложений западной части Алтае-Саянской складчатой области (новая версия) // Геология и минерально-сырьевые ресурсы Сибири. 2019а, № 8c. С. 69-105.

Сенников Н.В., Суяркова А.А. Межрегиональные граптолитовые зональные корреляционные интервалы силура России. Современные проблемы палеонтологии. Материалы LXI сессии Палеонтологического общества. - Санкт-Петербург, 2015. - С. 189191.

Сенников Н.В., Хабибулина Р.А., Обут О.Т., Новожилова Н.В., Токарев Д.А., Лучинина В.А. Терригенно-карбонатный тип седиментации в силуре Горного Алтая: строение, фациальные особенности, фаунистические комплексы и стратиграфическое положение // Геология и геофизика, 2019б. Т. 60, № 4. С. 532-554.

Соколова Л.В. Конодонты пограничных отложений силура и девона Полярного Урала (река Кожим) // Вестник Института геологии Коми НЦ УрО РАН, 2005. № 8. С. 2-4.

Стратиграфический кодекс России. Санкт-Петербург. Изд-во ВСЕГЕИ. Тр. МСК. 2019. 92 с.

Стратиграфической словарь СССР. Кембрий, ордовик, силур, девон. - Л.: Недра, 1975. -622 c.

Стратиграфической словарь СССР. Новые стратиграфические подразделения палеозоя СССР. - Л.: Недра, 1991. - 555 с.

Язиков А.Ю., Изох Н.Г. Биостратиграфия девона Салаира // Геология, геофизика и минеральное сырье Сибири: матер. 1-й науч.-практ. конф. Т. 1. Отв. ред. С.П. Зайцев. Новосибирск: СНИИГГиМС, 2014. С. 254-258.

Bakharev N.K., Izokh N.G., Yazikov A.Yu., Shcherbanenko T.A., Anastasieva S.A., Obut O.T., Saraev S.V., Peregoedov L.G., Khromykh V.G., Rodina O.A., Timokhina I.G., and Kipriyanova T.P. Middle-Upper Devonian and Lower Carboniferous Biostratigraphy of Kuznetsk Basin. Field Excursion Guidebook. Biostratigraphy, paleogeography and events in Devonian and Lower Carboniferous (SDS / IGCP 596 joint field meeting). July 20 - August 10, 2011, Novosibirsk. Novosibirsk. Publishing house SB RAS. 2011. 98 p.

Boncheva I., Sachanski V., Lakova I., and Yaneva M. Facies transition and biostratigraphic correlation of the Upper Silurian and Lower Devonian in West Bulgaria // Geol. Quart. 2007. Vol. 51, No 4. P. 407-418.

Calner M. Silurian global events - at the tipping point of climate change. In: Ashraf M.T. Elewa (ed.): Mass extinctions. Springer-Verlag. Berlin and Heidelberg. 2008. P. 21-58.

Corradini C. and Corriga M. G. Silurian and lowermost Devonian conodonts from the Passo Volaia area (Carnic Alps, Italy) // Bollettino della Società Paleontologica Italiana. - 2010. - Vol. 49. - No 3. - P. 237-253.

Corriga M.G. and Corradini C. Upper Silurian and Lower Devonian conodonts from the Monte Cocco II Section (Carnic Alps, Italy) // Bulletin Geosciences Czech Geological Survey. 2009. Vol. 84, No 1. P. 155-168.

Corriga M. G., Corradini C., and Ferretti A. Silurian conodonts from Sardinia: an overview // Rendiconti della Società Paleontologica Italiana. - 2009. - Vol. 3. - No 1. - P. 95107.

Cramer B.D., Brett C.E., Melchin M.J., Mannik P., Kleffner M.A., Mclaughlin P.I., Loydell D.K., Munnecke A., Jeppsson L., Corradini C., R. Brunton F.R., and Saltzman M.R. Revised correlation of Silurian Provincial Series of North America with global and regional chronostratigraphic units and $\delta^{13} \mathrm{C}_{\text {carb }}$ chemostratigraphy // Lethaia, 2011, vol. 44. P. 185-202.

Gradstein F.M., Ogg J.G., Smith A.G., and Ogg G.M. The Geologic Time Scale 2012. Vol. 1. Elsevier. 2012. 1144 p. 
Huskova A. and Slavik L. In search of Silurian/Devonian boundary conodont markers $n$ carbonate environments of the Prague Synform Czech Republic) // Palaeogeography, Palaeoclimatology, Palaeoecology. 2019, No 3. P. 1-49.

Kaljo D., Grytsenko V., Kallaste T., Kiipli T., and Martma T. Upper Silurian stratigraphy of Podolia revisited: carbon isotopes, bentonites and biostratigraphy // GGF. 2014. Vol. 136, No. 1. 136-141 p.

Lehnert, O., Frýda, J., Buggisch, W., and Manda Š. $\delta^{13} \mathrm{C}$ record across the Ludlow Lau Event: new data from mid palaeolatitudes of northern peri-Gondwana (Prague basin, Czech Republic) // Palaeogeogr., Palaeoclimatol., Palaeoecol., 2007a. Vol. 245. P. 227-244.

Lehnert, O., Eriksson, M.J., Calner, M., Joachimski, M., and Buggisch, W. Concurrent sedimentary and isotopic indications for global climatic cooling in the Late Silurian // Acta Palaeontologica Sinica, 2007b. Vol. 46. P. 249-255.

Lehnert O., Männik P., Joachimski M.M., Calner M., and Frýda J. Paleoclimate perturbations before the Sheinwoodian glaciation: A trigger for extinctions during the 'Ireviken Event’ // Palaeogeography, Palaeoclimatology, Palaeoecology. 2010. T. 296. P. 320-331.

Mathieson D., Mawson R., Simpson A.J., and Talent J.A. Late Silurian (Ludlow) and Early Devonian (Pragian) conodonts from the Cobar Supergroup, western New South Wales, Australia // Bulletin of Geosciences. - 2016. - Vol. 91. - No 3. - P. 583-652.

Munnecke A., Calner M., Harper D.T., and Servais T. Ordovician and Silurian sea-water chemistry, sea level, and climate: A synopsis // Palaeogeography, Palaeoclimatology, Palaeoecology. 2010. V. 296. P. 389-413.

Murphy M.A., Valenzuela-Ríos J.I., and Carls P. Classification of the Pridolian (Late Silurian) - Lochkovian (Early Devonian) Spathognathodontidae. University of California, Riverside Campus Museum Contribution. 2004. Vol. 6. P. 1-22.

Sennikov N.V., Yolkin E.A., Petrunina Z.E., Gladkikh L.A., Obut O.T., Izokh N.G., and Kipriyanova T.P. Ordovician-Silurian Biostratigraphy and Paleogeography of the Gorny Altai. Novosibirsk. Publishing House of SB RAS. 2008. 154 p.

Slavik L. and Carls P. Post-Lau Event (Late Ludfordian, Silurian) recovery of conodont faunas of Bohemia // Bulletin of Geosciences. - 2012. - Vol. 87. - No 4. - P. 815-832.

Slavik L., Kriz J., and Carls P. Reflection of the mid-Ludfordian Lau Event in conodont faunas of Bohemia // Bulletin of Geosciences. - 2010. Vol. 85, No 3. P. 395-414.

Slavik L., Storch P., Manda S., and Fryda J. Integrated stratigraphy of the Ludfordian in the Prague Synform // GFF. - 2014. - vol. 136. - No 1. - P. 238-242.

Spiridonov A. and Brazauskas A. Comparative analysis of ontogeny and ecomorphology of the "Ozarkodina remscheidensis" (Conodonta: Ozarkodinida) species group in the Upper Ludlow and Pridoli of Lithuania // Paleontol. Journ. 2014. Vol. 48. P. 1104-1114.

Spiridonov A., Brazauskas A., Meidla T., Ainsaar L. Quantifying the community turnover of the uppermost Wenlock and Ludlow (Silurian) conodonts in the Baltic Basin // Palaeogeography, Palaeoclimatology, Palaeoecology. 2019. March. P. 1-31. (DOI: 10.1016/j.palaeo.2019.03.029)

Spiridonov A., Stankevic R., Gecas T., Brazauskas A., Kaminskas D., Musteikis P., Kaveckas T., Meidla T., Bickauskas G., Ainsaar L., and Radzevicius S. Ultra-high resolution multivariate record and multiscale causal analysis of Pridoli (late Silurian): implications for global stratigraphy, turnover events, and climate-biota interactions // Gondwana Research. 2020. P. 1-69. (DOI: 10.1016/j.gr.2020.05.015) 


\section{подПиси}

к рисункам статьи Сенников Н.В. и др. «Строение и биостратиграфическая характеристика пржидольского отдела силура на Горном Алтае»

Рис. 1. Схема расположения рассматриваемого района Горного Алтая.

А, Б - структурно-фациальные зоны с полями выходов силура (А - Ануйско-Чуйская, Б Чарышско-Инская); В - зона сдвигов крупнейших региональных блоков; Г - район исследований; Д - местоположение изученных разрезов (I - Черный Ануй-2, II - Бурта-3, III - Марагда-5, IV - Марагда-4); Е - тектонические нарушения; Ж - границы пакетов пачек; 3 - элементы залегания. Остальные условные см. рис. 3.

Рис. 2. Сопоставление схем стратиграфического расчленения местных и региональных стратиграфических подразделений верхней части силура Горного Алтая и трансформация взглядов на возраст стратонов.

Ануй-2.

Рис. 3. Строение и распространение фаунистических остатков в разрезе Черный

Условные обозначения см. рис. 4.

Рис. 4. Строение и распространение фаунистических остатков в разрезе Бурта-3.

1 - конгломераты; 2 - гравелиты; 3 - песчаники с плавающей галькой и гравием; 4 песчаники, 5 - алевролиты; 6 - аргиллиты; 7 - терригенные породы с известковым цементом; 8 - известняки глинистые; 9 - известняки песчанистые; 10 - известняки органогенно-обломочные, комковатые; 11 - известняки массивные; 12 - биогермы; 13 задернованный интервал.

Рис. 5. Конодонты разреза Бурта-3

Все конодонтовые элементы из 9-ой пачки разреза «Бурта-3», силур, лудловский отдел, лудфордский ярус, куимовский горизонт, куимовская свита.

Фиг. 1, 2, 7, 14, 15 - Ozarkodina sp. - Ра-элементы; (1 - эк3. №2100-41; 2 - эк3. №2100-42; 7 - эК3. №2100-43; 14 - эК3. №2100-54; 15 - эК3. № 2100-57).

Фиг. 3-6, 9, 10 - Ozarkodina cf. confluens (Branson et Mehl, 1933); 3 - Рb-элемент (3 - экз. № 2100-44); 4 - М-элемент (4 - экз. № 2100-46); 5, 6 - Sb-элементы (5 - экз. № 2100-50; 6 экз. № 2100-51); 9, 10 - Ра-элементы (9 - экз. № 2100-52; 10 - эк3. № 2100-53).

Фиг. 8, 11-13, 16, 17, 20 - Zieglerodina remsheidensis (Ziegler, 1960); 11 - М-элемент (11 экз. № 2100-47); 12, 16 - Рb-элементы (12- экз. № 2100-49; 16 - экз. № 2100-59); 13 - Sbэлемент (13 - экз. № 2100-48); 17 - Sа-элементы (17 - экз. № 2100-55); 8, 20 - Ра-элемент (8 - эК3. № 2100-45; 20 - эК3. № 2100-60).

Фиг. 18 - Ozarkodina cf. confluens (Branson et Mehl, 1933); экз. № 2100-58; (Ра-элемент).

Фиг. 19 - Zieglerodina cf. remsheidensis (Ziegler, 1960); экз. № 2100-56; (Ра-элемент).

Фиг. 21 - Zieglerodina remsheidensis (Ziegler, 1960); экз. № 2100-40; (Ра-элемент).

Рис. 6. Строение и распространение фаунистических остатков в разрезе Марагда-5. Условные обозначения см. рис. 4.

Рис. 7. Конодонты разрезов Марагда-5 и Марагда-4.

Фиг. 1, 4, 10 - Ozarkodina eosteinhornensis (Walliser, 1964); 1, 4 - Ра-элементы (1 - экз. № 2100-34; 4 - экз. № 2100-23); 10 - М-элемент (10 - экз. № 2100-35); разрез Марагда-5, 9-ая пачка; силур, пржидольский отдел, куимовский горизонт, куимовская свита.

Фиг. 2 - Ozarkodina cf. multistriola Mathieson in Mathieson et al., 2016; эк3. № 2100-24; разрез Марагда-5, 9-ая пачка; силур, пржидольский отдел, куимовский горизонт, куимовская свита. 
Фиг. 3, 7 - Panderodus sp.; (3 - экз. № 2100-39; 7 - экз. № 2100-37); разрез Марагда-5, 7-ая пачка; силур, лудловский отдел, лудфордский ярус, куимовский горизонт, куимовская свита.

Фиг. 5 - Pelekysgnathus sp.; экз. № 2100-22; разрез Марагда-5, 9-ая пачка; силур, пржидольский отдел, куимовский горизонт, куимовская свита. обр. 14071306

Фиг. 6 - Oulodus? sp.; экз. № 2100-32; обломок; разрез Марагда-5, пачка; силур, пржидольский отдел, куимовский горизонт, куимовская свита.

Фиг. 8 - Wurmiella excavata (Branson et Mehl, 1933); экз. № 2100-30; разрез Марагда-5, 7-ая пачка; силур, лудловский отдел, лудфордский ярус, куимовский горизонт, куимовская свита.

Фиг. 9 - Ozarkodina sp.; (Ра-элемент); экз. № 2100-31; разрез Марагда-5, 7-ая пачка; силур, лудловский отдел, лудфордский ярус, куимовский горизонт, куимовская свита.

Фиг. 11 - Panderodus sp.; экз. № 2100-20; разрез Марагда-5, 9-ая пачка; силур, пржидольский отдел, куимовский горизонт, куимовская свита.

Фиг. 13 - Ozarkodina sp.; экз. № 2100-33; (Ра-элемент); разрез Марагда-5, 9-ая пачка; силур, пржидольский отдел, куимовский горизонт, куимовская свита.

Фиг. 14 - Zieglerodina cf. remsheidensis (Ziegler, 1960); экз. № 2100-19; (Ра-элемент); разрез Марагда-5, 9-ая пачка; силур, пржидольский отдел, куимовский горизонт, куимовская свита.

Фиг. 15 - Обломок конодонтового элемента (gen. et sp. indet.); экз. № 2100-27; разрез Марагда-4, 5-ая пачка; силур, лудловский отдел, лудфордский ярус, куимовский горизонт, куимовская свита.

Фиг. 16 - Ozarkodina cf. snajdri (Walliser, 1964); экз. № 2100-26; (Ра-элемент); разрез Марагда-4, 5-ая пачка; силур, лудловский отдел, лудфордский ярус, куимовский горизонт, куимовская свита. обр.

Фиг. 17 - Ozarkodina sp. indet.; экз. № 2100-36; разрез Марагда-4, 1-ая пачка; силур, лудловский отдел, лудфордский ярус, куимовский горизонт, куимовская свита.

Фиг. 18 - Panderodus unicostatus Branson et Mehl, 1933; экз. № 2100-38; разрез Марагда-4, 1-ая пачка; силур, лудловский отдел, лудфордский ярус, куимовский горизонт, куимовская свита.

Фиг. 19 - Oulodus sp.; экз. № 2100-28; разрез Марагда-4, 1-ая пачка; силур, лудловский отдел, лудфордский ярус, куимовский горизонт, куимовская свита.

Фиг. 20 - Wurmiella excavata (Branson et Mehl, 1933); экз. № 2100-25; (Ра-элемент); разрез Марагда-4, 1-ая пачка; силур, лудловский отдел, лудфордский ярус, куимовский горизонт, куимовская свита.

Фиг. 21 - Oulodus sp.; экз. № 2100-29; разрез Марагда-4, 5-ая пачка; силур, лудловский отдел, лудфордский ярус, куимовский горизонт, куимовская свита.

Рис. 8. Строение и распространение фаунистических остатков в разрезе Марагда-4. Условные обозначения см. рис. 4.

Рис. 9. Конодонты разреза Черный Ануй-2.

Фиг. 1, 2, 4-8, 15 - Icriodus cf. angustoides Carls et Gandl, 1969; 1, 2, 4, 5 - платформенные I - элементы (1, 2 - экз. № 2100-1; 4 - экз. № 2100-2; 5 - экз. № 2100-3), 7, 15 - S-элементы (7 - эКз. № 2100-8; 15 - эКз. № 2100-13), 6, 8 - Рь-элементы (6 - эк3. № 2100-7; 8 - эк3. № 2100-10); разрез Черный Ануй-2, 18-ая пачка; нижний девон, интервал лохковского и пражского ярусов, елбакский горизонт, черноануйская свита.

Фиг. 3 - Zieglerodina mashkovae (Drygant, 1984); (Ра-элемент); экз. № 2100-4; разрез Черный Ануй-2, 18-ая пачка; нижний девон, интервал лохковского и пражского ярусов, елбакский горизонт, черноануйская свита. 
Фиг. 9 - (?) Eognathodus sp.; экз. № 2100-9; разрез Черный Ануй-2, 18-ая пачка; нижний девон, интервал лохковского и пражского ярусов, елбакский горизонт, черноануйская свита.

Фиг. 10 - 14 - Icriodus cf. curvicauda Carl et Gandl, 1969; 10, 11 - платформенные Iэлементы (10 - экз. № 2100-5; 11 - экз. № 2100-6), 12-14 - конические S-элементы (12 - экз. № 2100-11; 13 - экз. № 2100-15; 14 - экз. № 2100-12), разрез Черный Ануй-2, 18-ая пачка; нижний девон, интервал лохковского и пражского ярусов, елбакский горизонт, черноануйская свита.

Фиг. 16, 17 - Peleksygnatus sp.; экз. № 2100-14; разрез Черный Ануй-2, 10-ая пачка; силур, пржидольский отдел, чергинский горизонт, черноануйская свита.

Фиг. 18 - Ozarkodina sp.; экз. № 2100-16; (Ра-элемент); разрез Черный Ануй-2, 10-ая пачка; силур, пржидольский отдел, чергинский горизонт, черноануйская свита.

Фиг. 19 - Peleksygnathus sp.; экз. № 2100-17; разрез Черный Ануй-2, 20-ая пачка; силур, пржидол, чергинский горизонт, черноануйская свита.

Фиг. 20 - Panderodus sp.; экз. № 2100-18; разрез Черный Ануй-2, 10-ая пачка; силур, пржидольский отдел, чергинский горизонт, черноануйская свита. 


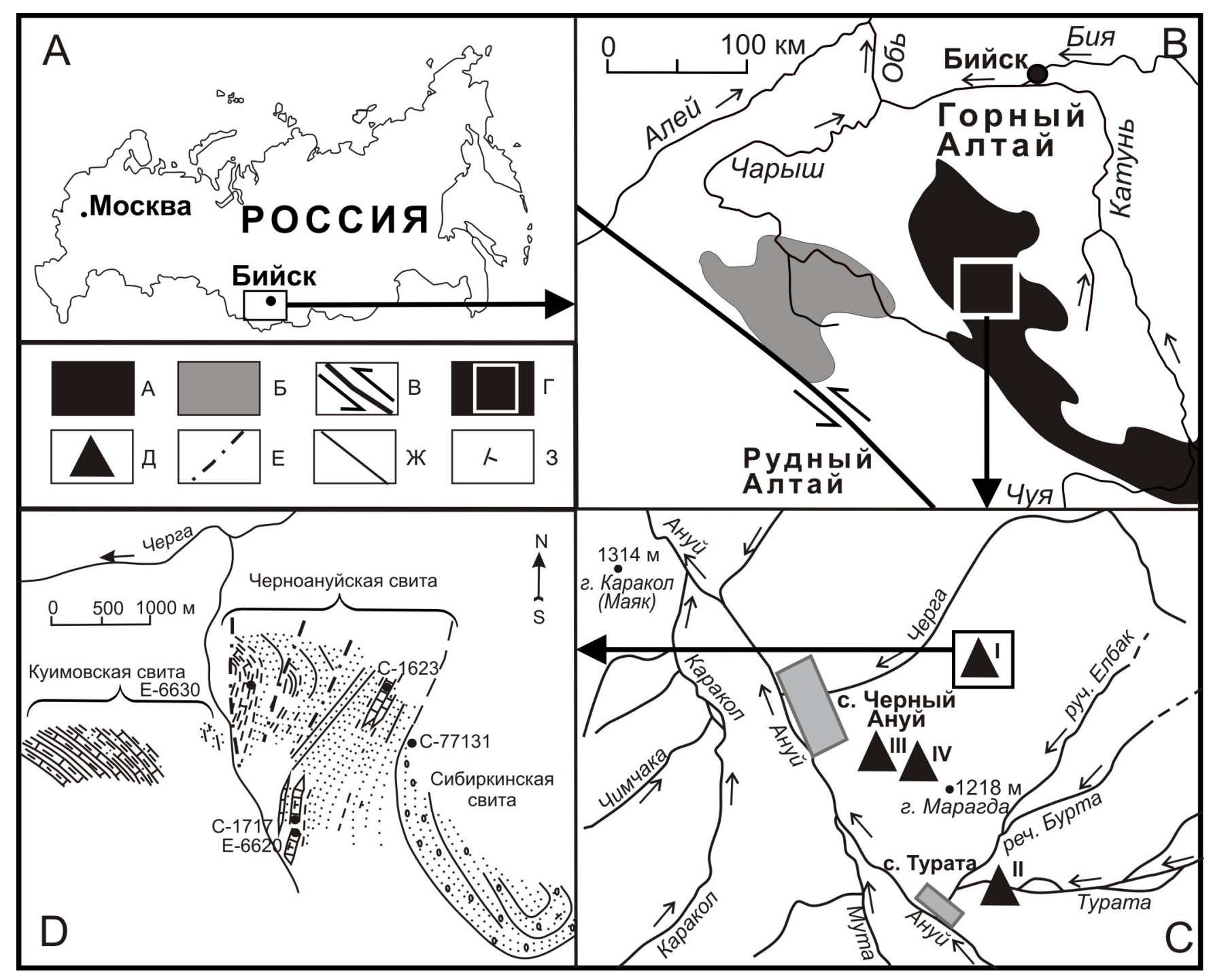




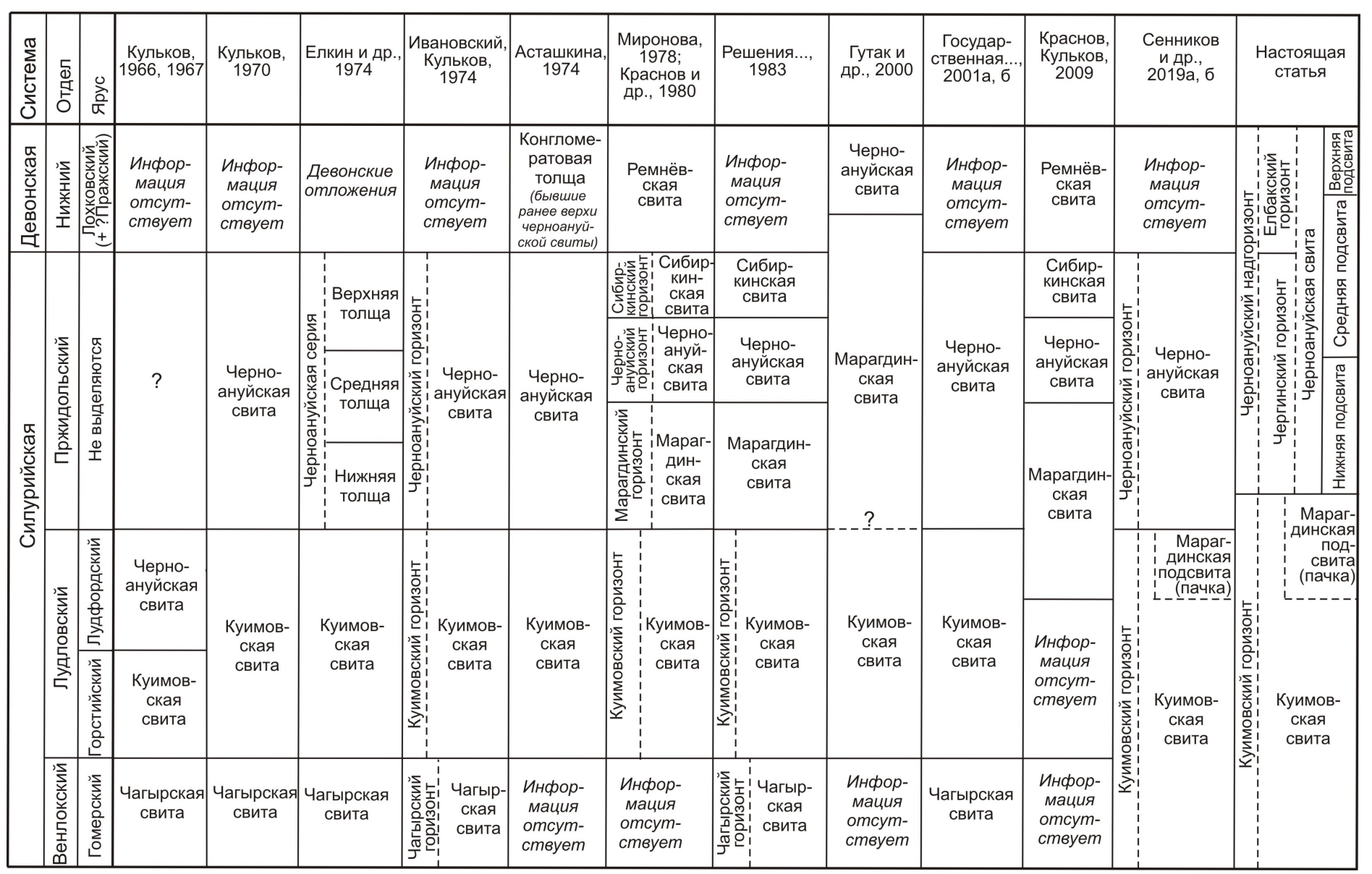




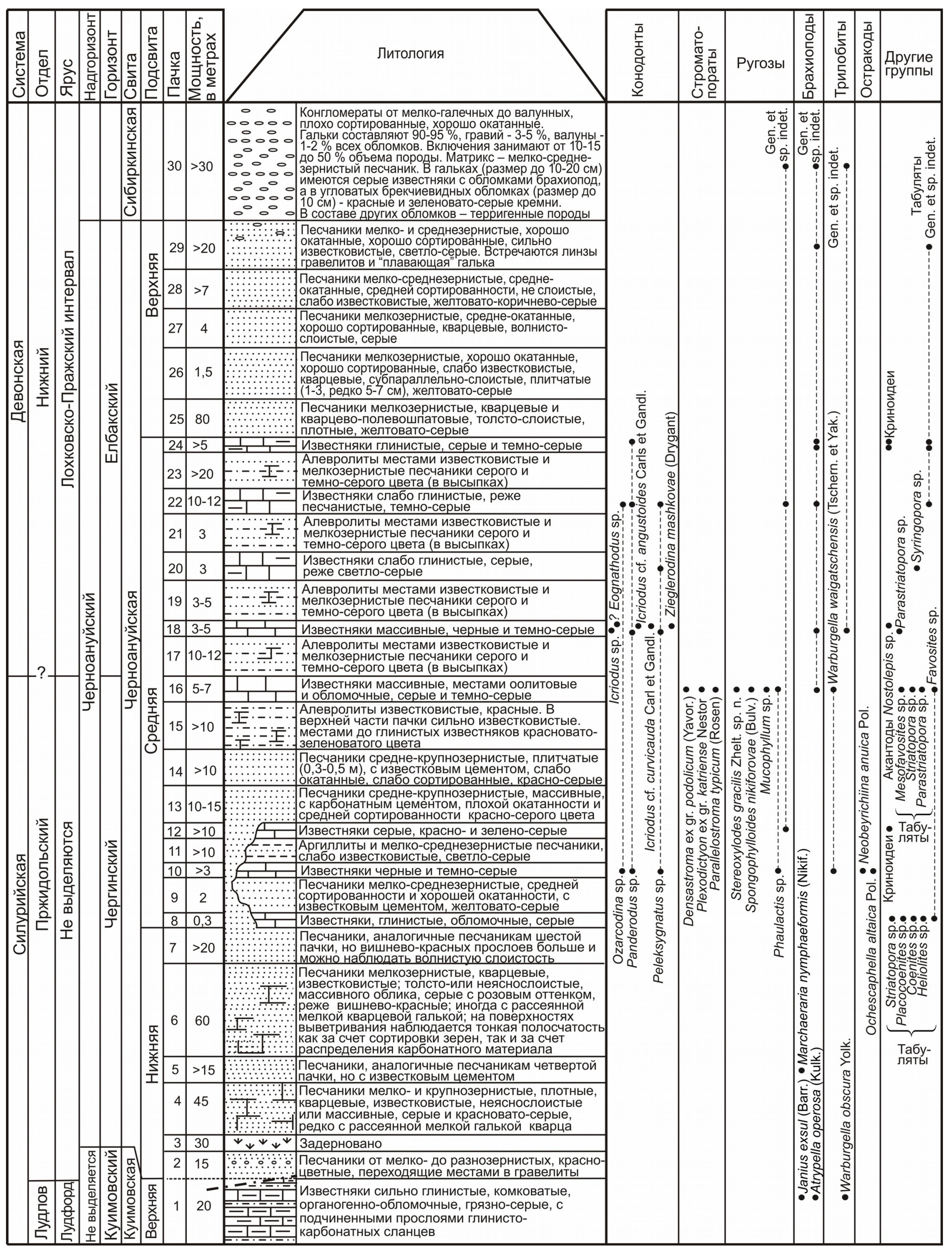




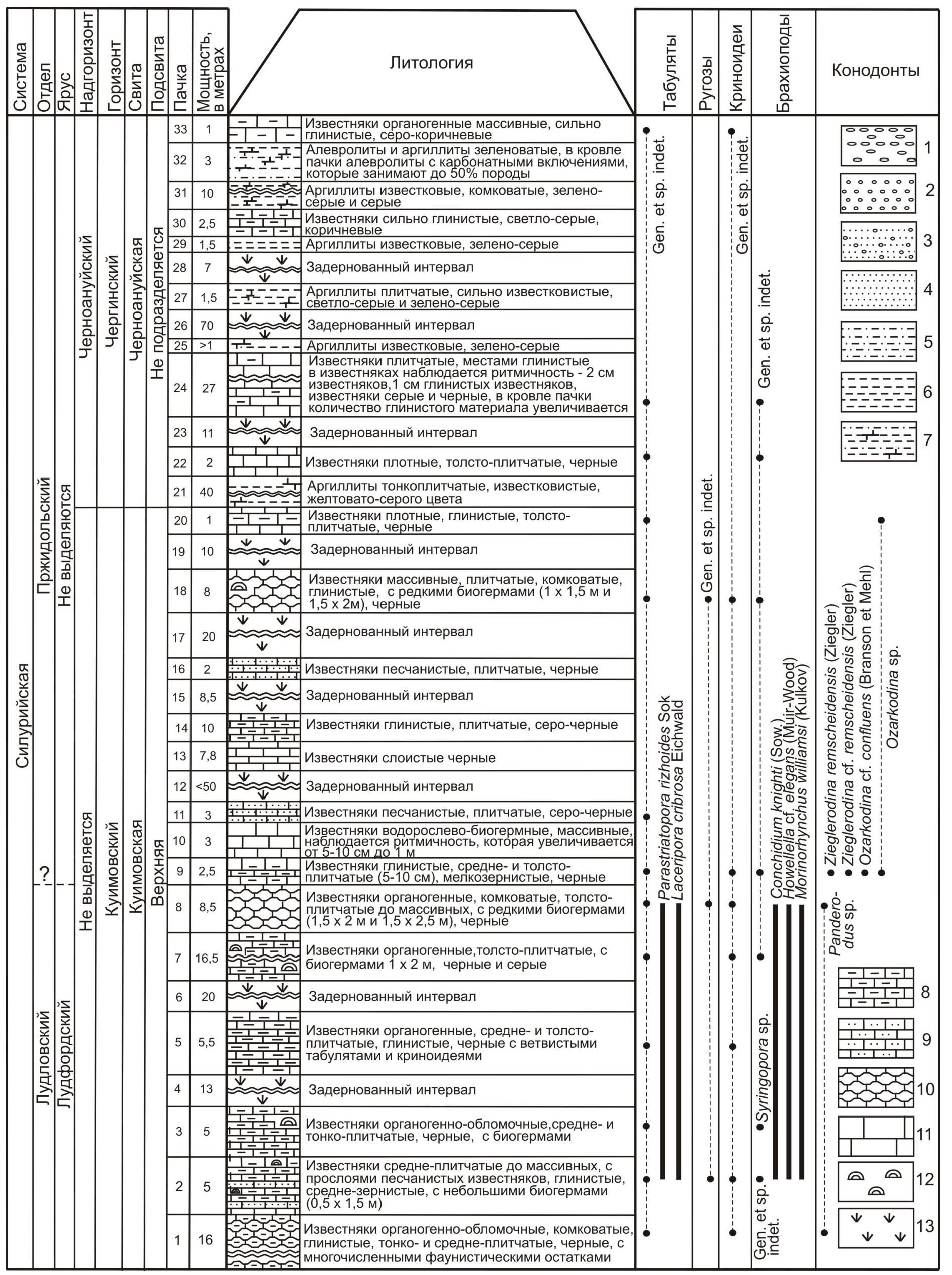




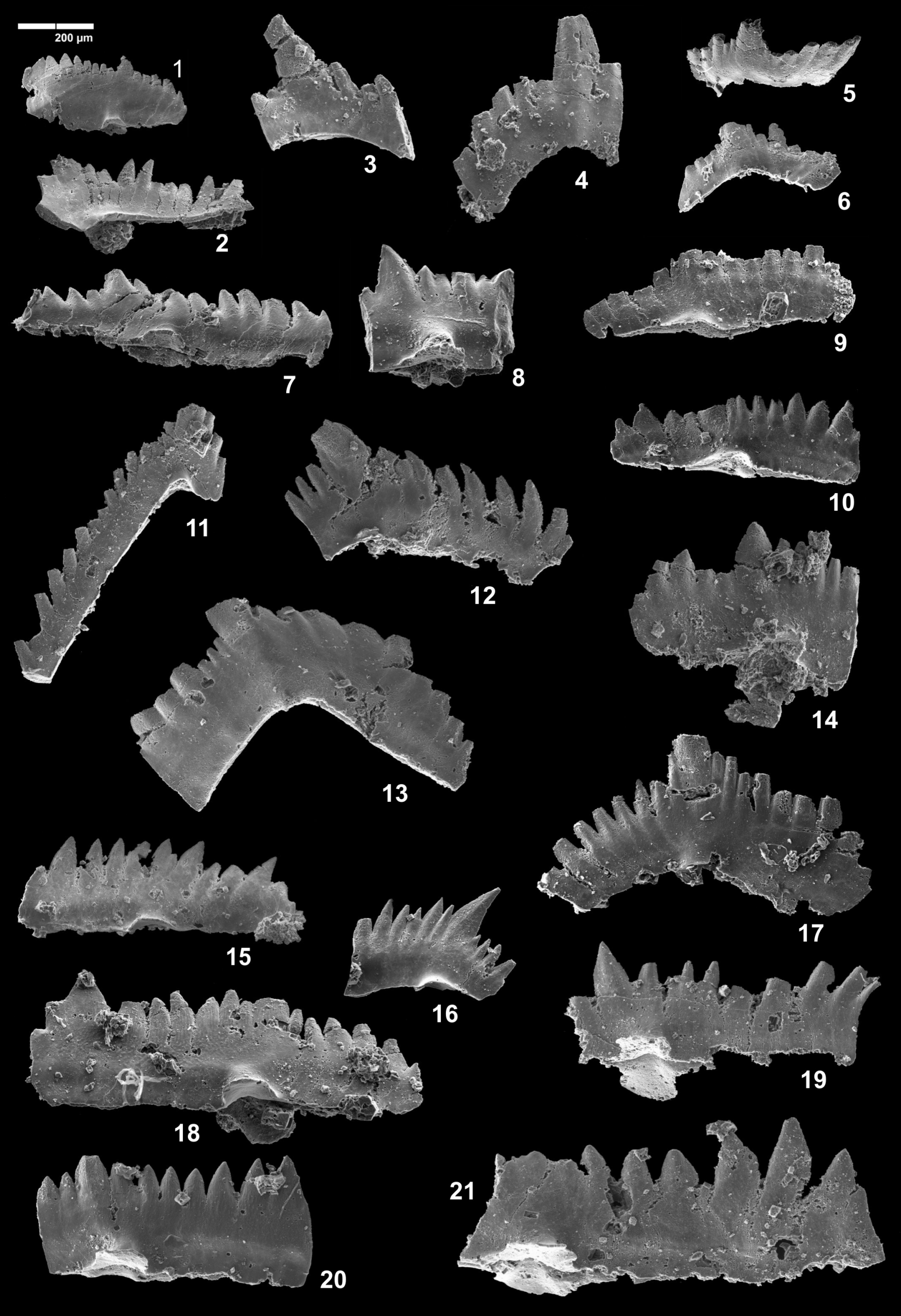




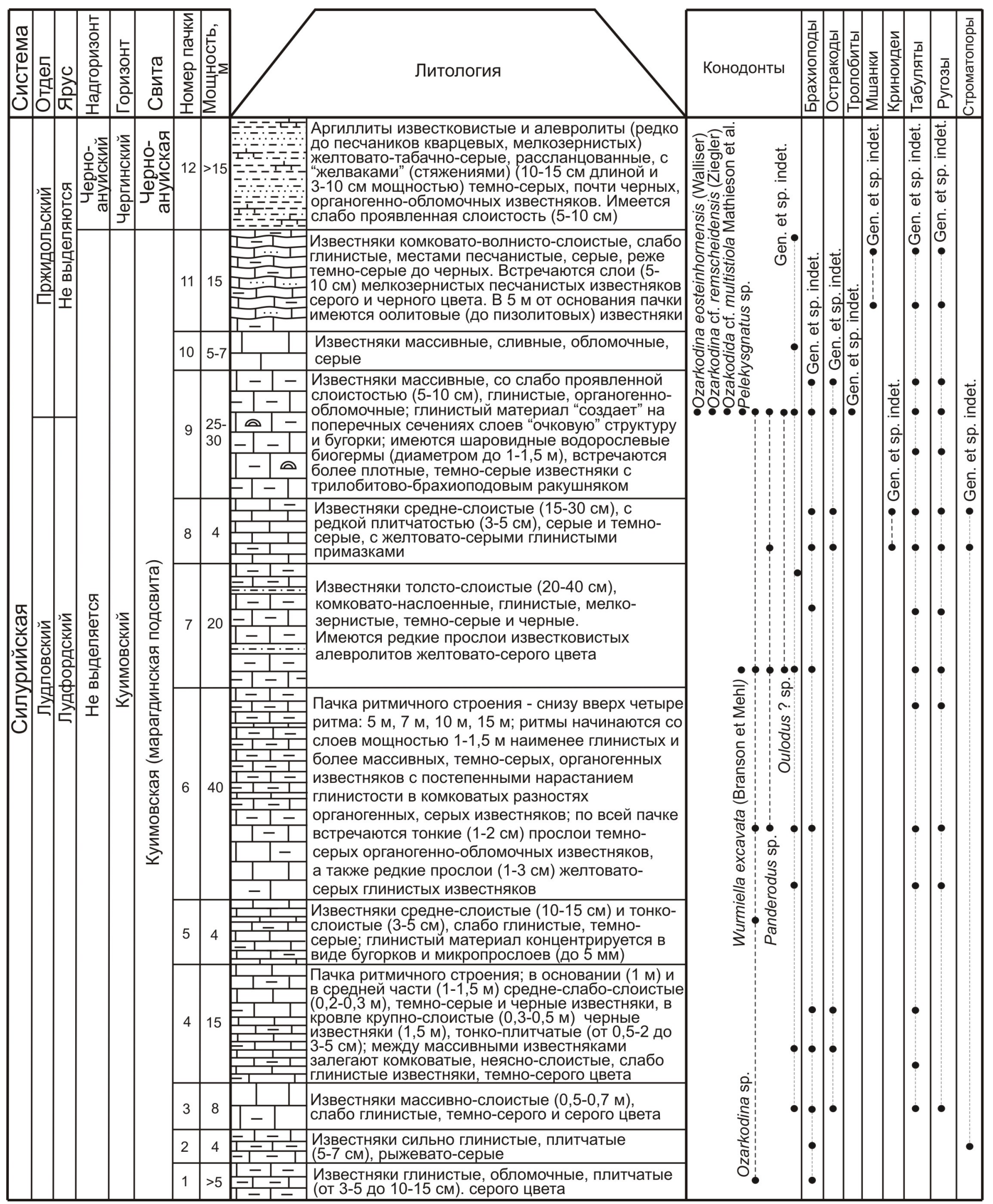




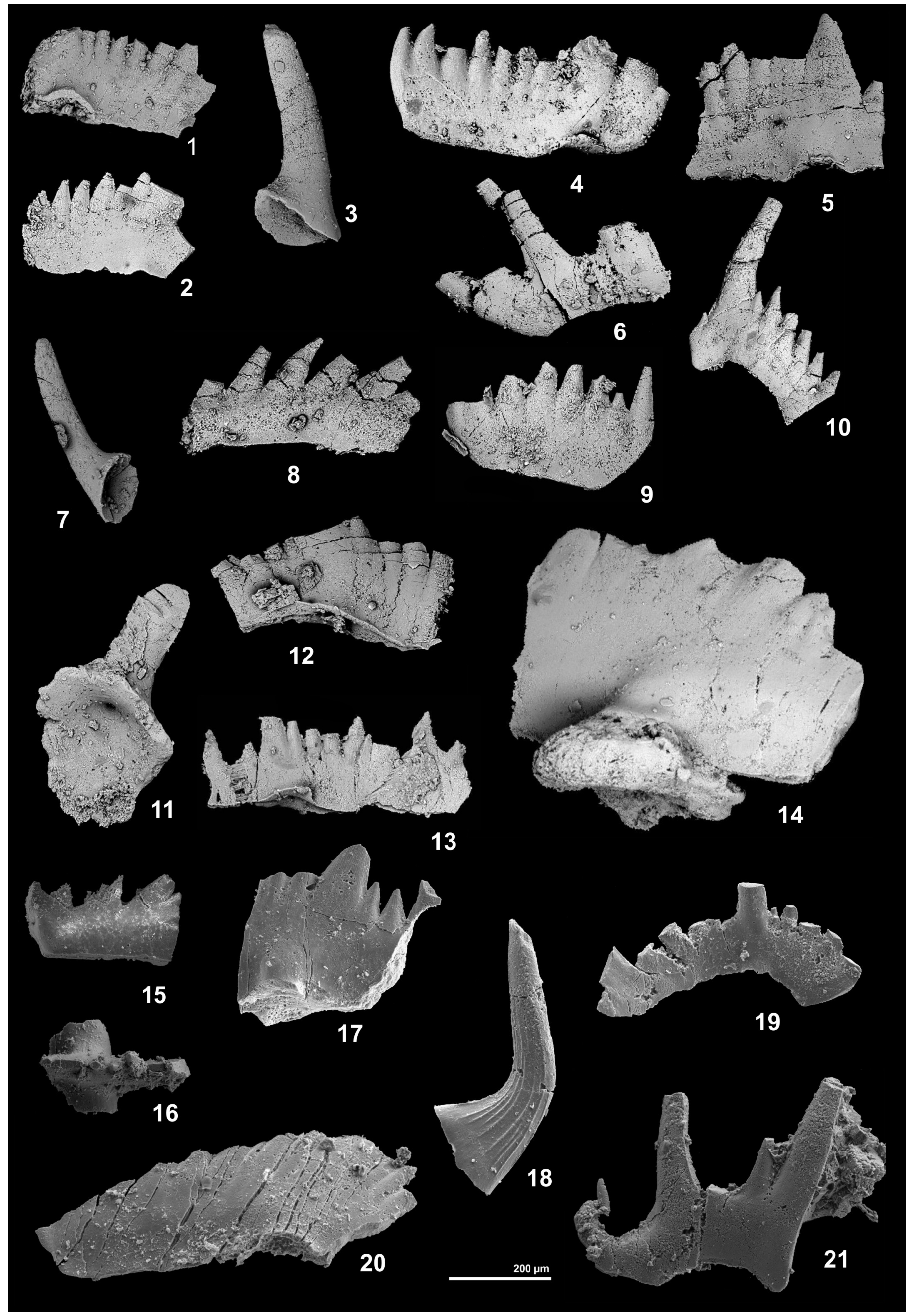




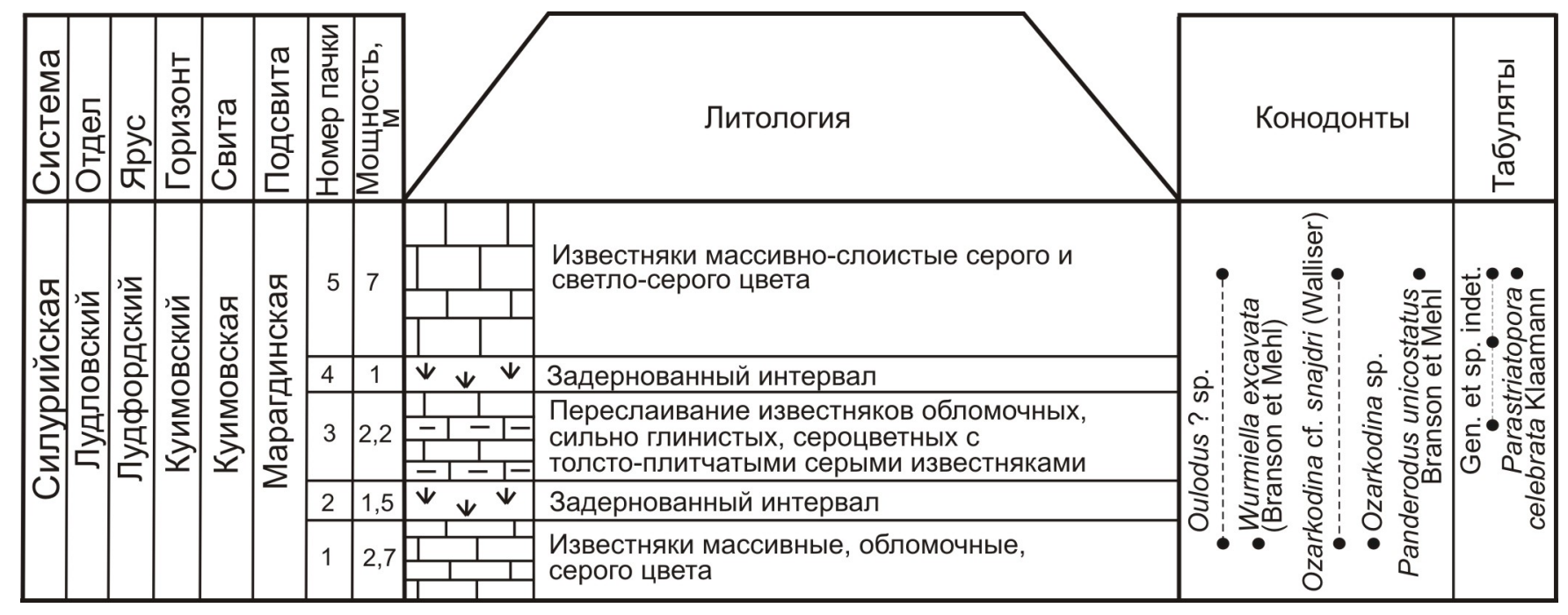



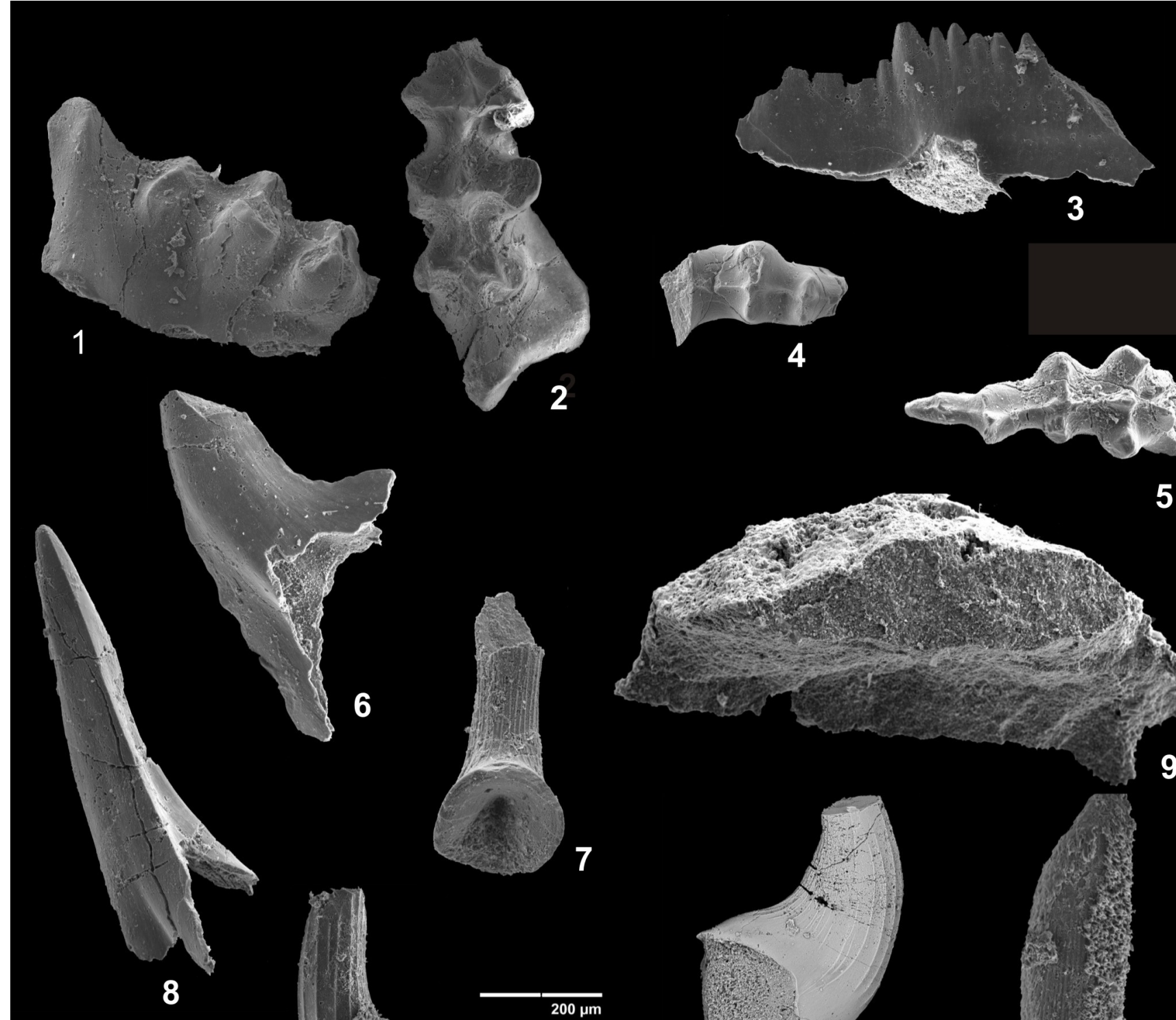

2
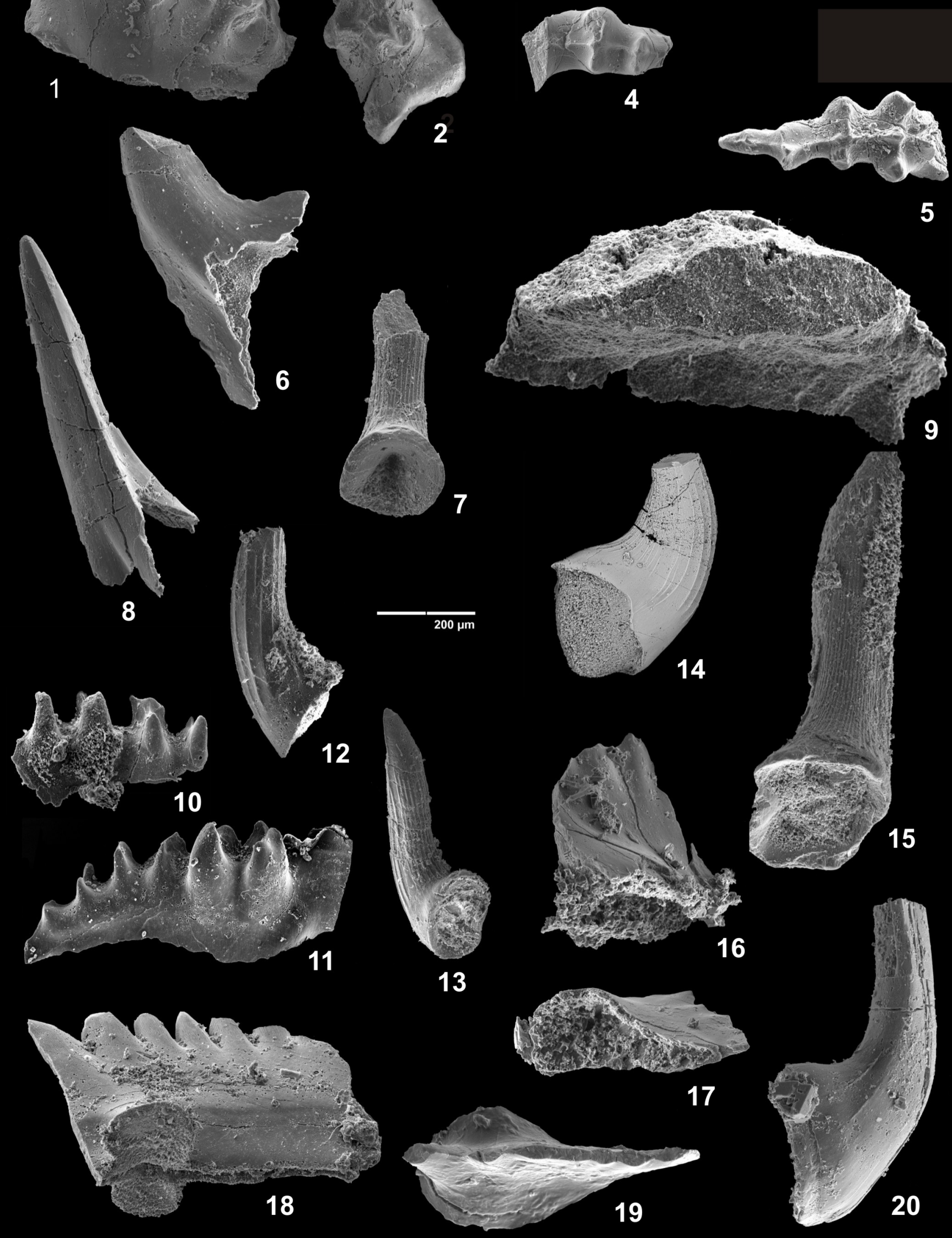